\title{
From Grammar to Critical Thinking in Seven Steps at 2013 KOTESOL DCC Symposium
}

\author{
Paul Roger Friesen \\ Woosong University, Daejon City, South Korea
}

\begin{abstract}
“From Grammar to Critical Thinking in Seven Steps” was presented at the 2013 KOTESOL DCC Symposium, Woosong University, 2013. The purpose of the project was to accelerate the learning curve of students with a higher than average IQ (intelligence quotient), but functionally low in English. The students were required to write an essay, in the last hour of a four hour class. The students were challenged to fix sentences, write the reason they chose, and speak their answer. To determine if this was a one book idea, another test was tried with regular students, using an off the shelf grammar book. Using the same step by step process, the ability of students to make a story, from a standard grammar book, was accomplished in a 90-minute class. Students enjoyed the activity and were able to use previously learned ideas in their sequencing and logical choices. This in turn strengthened the writing process, which was the goal. After four sessions, students in the initial trial class achieved better writing and story development skills. The second group did not continue the process due to class and schedule changes. Their understanding of the process was enlarged, but not tested.
\end{abstract}

Keywords: learning curve, function, essay, end goal, story, grammar

\section{Introduction}

Knowing grammar is only one component of English. Linking grammar to other elements or dimensions can enhance the students' enjoyment. The seven steps outlined bring several areas into focus. From a basic list of grammar sentences, through to logical thinking, sequencing, prepositions, and conjunctions to fill in the gaps, this simple process will give the teacher and student a multi-faceted look at what seems to be a boring and often mundane lesson.

\section{From Grammar to Critical Thinking in Seven Steps}

Many students find it difficult to incorporate the grammar they learn into their writing exercises. In South Korea, students have been taught grammar in both public and private schools. Yet, much of the writing you get as a teacher is wrought with structural mistakes. Is it that the student does not know the grammar, or is it that they have never transferred the knowledge to a different form?

For example, to go from basic grammar to essay or story-making seems like a big step. This transfer of information requires that students change their native language grammar defaults to fit the new requirements. In Hangul, the structure is different and there are no articles. Teaching the articles and how

Paul Roger Friesen, professor, D.Min., Department of General English Language, Woosong University. 
they function can be a great exercise. If the knowledge is not transferred to a more tangible entity, the knowledge remains dormant.

In the first test, Ms. Song, a teacher at the IECG (International Education for Gifted Children), a program established at Pyoungtaek University, Korea, was tasked with how to accelerate the learning curve of this class. She used Dr. Roy's Everything Grammar Vol. I (Friesen, 2013) as a starting point. The result was that students caught on very quickly to the system in the book. The challenge was how to expand the learning using the same material. Due to government regulations, IECG closed in August, 2013.

\section{Method}

\section{Participants (Group 1)}

Students ranged in school level, grades 3-5, and were tested at the Pyoungtaek University IECG program by Dr. Song (Ph.D.) to have IQ’s (intelligence quotient) higher than 130. The testing was done to determine if the student met the minimum IQ requirement, using standard psychological testing programs, in Korea. An additional English level test was also given to determine which class the student would join. All students, in the first group, were tested low in English ability but high in IQ. There were from six to 10 students in the class on a regular basis. The class was run for four hours, every Saturday, for a period of three months. The last hour, in the four hour class, was an essay writing exercise. In this class, there were also reading and visualization exercises. These steps were performed over a period of two or three one hour periods.

\section{Participants (Group 2)}

The second group was comprised of private school students (hogwon) in South Korea. The school level was the 2nd or 3rd year of Middle School, in South Korea. There was no entry requirement other than school grade. There were eight students in the class. The author had taught them every Saturday for about a year. In their regular school class, they all rated in the top 10 in English scores. This class was a 90-minute class. There was no break. All seven steps were performed during one class period.

\section{Materials and Procedures}

In the first group, the book used was Dr. Roy's Everything Grammar Vol. I. A selection of sentences used in the "Nouns" (Friesen, 2013) section were chosen. The books process includes mapping, rewriting, and creation of a logical sequence, of a sentence to speak in class (see Example (1)). This was followed by writing the reason for their choices. The final step was to speak the reason in class to better imprint the memory.

Example (1) The Basic Sentence/Nouns: p. 20

$$
\text { sub pred }
$$

2. My father cut the grass. father / cut the grass

Speaking = My father is the subject and cut the grass is the predicate. (Friesen, 2013)

This improved the students' ability to discover nouns in their reading, but did not help the student put ideas together. Example (2) is a short list of sentences in the same section. They are disjointed, with no apparent direction or connection. This accelerated the learning curve for parts of grammar recognition, while the writing improved marginally. The students were given a list of sentences comprised of one A4 page (approximately 30). 
Example (2) Sample short list

3. He waved to me.

4. A pencil lay on the desk.

5. John went to the game.

6. The fire. (Friesen, 2013, p. 20)

In the second group, the book Grammar Zone Workbook 2 (2006) was used. This was an off the shelf book frequently taught in private Korean school classes. It was comprised of both Hangul and English texts (see Appendix 3). The book is tense oriented versus the parts of speech orientation in the first text. After scanning about three pages, the Hangul was removed, leaving only English sentences (see Appendix 1). There was no predisposition or a cutting out of sentences that were repeated. There was also no predisposed choice of tense. This is called "Step 1". Choosing a unit or set amount of text which gives adequate English text is important. Each book and unit will be different.

\section{Step 2: Common Threads}

Having passed out the paper with the sentences to the students, the task was to find common threads, or topics. Often there are similar topics in one book section. Dr. Roy's Everything Grammar Vol. I has perhaps more variation, due to its focus on parts of speech.

In Step 2, the task was to find as many different topics as possible. Each topic was numbered starting from "1". There was no limit to how many topics they could choose. Later they would need to combine the topics with the least sentences to match the number of students. This was difficult for all students. It was a different approach so scaffolding and close supervision was needed to facilitate the numbering. This was an important part of the process, as the end goal was to use the groups of sentences, to make a story. This took the most time, but would be less cumbersome once the system was better understood through repetition. The students chatted in English about what topics they found. This speaking helped students become more engaged as they participated, as individuals, in a group. The number of topics chosen was based on the number of students. There were eight students, so we combined two smaller but similar topics to facilitate this deficit. A complete list of numbered lines can be found in Appendix 1.

\section{Step 3: Separation}

This step was to separate the sentences into their numbers. Therefore, all the sentences numbered " 1 " were put together. The students found nine different topics (see Appendix 1). The list of sentences numbered " 1 " is listed below.

1 I've turned off the computer. So the computer is off now.

1 I turned off the computer last night. I don't know if it's off or on now.

1 Can I use your cell phone?

1 Sorry. I've left it at home. So I don't have it now.

1 Do you know Lisa's e-mail address?

1 Oh, I'm sorry. I've forgotten it. So I don't know it now.

1 I forgot her e-mail address, so I couldn't e-mail her.

1 I've already searched the Internet but found nothing.

1 Have you ever bought anything on the Internet?

1 Sure. I've bought lots of things so far. In fact, just yesterday I bought some books online. (Thomas, Beard, \& Cant, 2005, pp. 28-32). 
The topic choice was all the students' choice. The topic they chose was related to the idea of computer or cell phone. In this step, the students were tasked only with separating and rewriting the numbered sentences into a list. Korean students do not write in paragraphs naturally. Using their default grammar style, which was a list, was a natural starting point to making paragraphs. In this section, students conferred with each other collaboratively to number each sentence. This speaking and collaboration are important in the learning curve acceleration.

\section{Step 4: Combining sentences}

In this step, the students were tasked with making a paragraph using the listed sentences. Having a class of only eight students, each student was given a number to work with. One student was assigned all the " 1 " numbered sentences, etc.. This required the students to not only rewrite the sentences out in paragraph form, but also to choose a sequence of events. This proved to be a challenge. There are similar ideas which made the choice difficult. Initially, students just rewrote the sentences in a paragraph form which was similar to Example (3) below.

Example (3) Rewriting into a paragraph

I've turned off the computer. So the computer is off now. I turned off the computer last night. I don't know if it's off or on now. Can I use your cell phone? Sorry. I've left it at home. So I don't have it now. Do you know Lisa's e-mail address? Oh, I'm sorry. I've forgotten it. So I don't know it now. I forgot her e-mail address, so I couldn't e-mail her. I've already searched the Internet but found nothing. Have you ever bought anything on the Internet? Sure. I've bought lots of things so far. In fact, just yesterday I bought some books online.

This step took more time. The students were a bit confused initially, but were able to make good choices, once they read the paragraph through several times. This was done on an individual level. The teacher worked with individuals when there was a question or clarification needed. At this point, each student had made a paragraph and sequenced the sentences correctly.

\section{Step 5: Fill the gap}

In this step, students were tasked to fill the gaps of information. This meant that the words and ideas which were repeated would be cut out. Using Example (3) as an example, we find that some ideas are close but need a link to make them fit together. In other paragraphs, there needed a complete sentence to create the link. Having students work with one paragraph in this step is important. Students saw the ideas, but were perplexed as to how to link them. Once they separated ideas into topic areas (see Example (4)), the students saw what they needed to do. This helped the students fill in the links with simple sentences, phrases, or parts of speech they already know. Once students understood how they could separate their ideas and build links, the process was accelerated. The complete list can be viewed (see Appendix 2).

Example (4) Sentence topic separation

Computer-I've turned off the computer last night. So the computer is off now. I don't know if it's off or on now.

Cell phone-Can I use your cell phone? Sorry. I've left it at home. So I don't have it now.

Email—Do you know Lisa's e-mail address? Oh, I'm sorry. I've forgotten it, so I couldn't e-mail her. I've already searched the Internet but found nothing. Have you ever bought anything on the Internet? Sure. I've bought lots of things so far. In fact, just yesterday I bought some books online. 


\section{Step 6: Linking}

Linking the ideas puts the sequence of thought together. Sequencing is important and takes time. In Step 6, the students were tasked with adding the connectors or the small words and prepositions in the sentences to smooth out the reading. Small words are important and are often missed in the student's writing process. Prepositions are often lacking in students writing or speaking due to their default language. Each student revisited their paragraph to add these connectors plus punctuation. For some, this proved difficult. Not because they did not know the parts of speech or the punctuation, but because they had to go from a list to a collection of integrated ideas. Rewriting the sentences several times allowed students to visualize the paragraph better. Once they could visualize the paragraph, the connections were easily found and inserted.

\section{Step 7: All in one}

Students at this step collaborated again to make the story. There were eight students, therefore, eight paragraphs. Some were short and others long. Students were required to discuss the order, in which they should put their paragraphs. The discussion required each student to revisit the whole story by topic and offer their opinion to the group for acceptance. Discussion was vibrant and active. Once the students had decided on the order, each student read their paragraph in turn.

\section{Results}

The results of this exercise were twofold. In the first group, the acceleration to writing an essay which was the goal was accomplished. The advantage of this method was the students did not get stressed on grammar, but on learning the recognition and function of determiners. The ability to write more effective sentences was accelerated. In less than a month, the students were writing short essays. Essay writing was a required exercise in the last hour of the class. The goal of accelerating the student's ability to write better essays was achieved. The simplicity of the technique proved to accelerate the learning curve.

The results in the second group were a better understanding of how to link, sequence, and write more effectively. The focus of a private English school is test preparation. The results of this exercise were better scores in their school tests. The advantage of this method was to develop a better understanding of how to link ideas. This new understanding, when included in a reading program, could develop a faster reading proficiency. This in turn would improve test scores, which are crucial, in South Korea. This test also proved that grammar does not have to be boring, or the book changed. Using the standard books used in the classroom, a teacher can provide a broader spectrum of ideas to integrate the students' learning in other areas of English, such as literature, reading, etc.. Though the clarity of the idea in one class was limited the acceleration of learning was not inhibited.

\section{Discussion}

The two test groups were limited in scope. The first group was small and had four hours to work. Each hour was assigned an activity. The second was a one class test. Future discussion using these steps could focus on expanding both styles.

The first method using parts-of-speech material would need to determine if the steps worked equally throughout the book. Using the parts-of-speech style of book could also be tested for its integrative value into 
other areas of English learning in a standard curriculum. The ability to build an essay over a compressed time schedule was achieved. This method needs to be tested to see if students can in a longer test write in a more logical sequence naturally. This is important, because students do not naturally write in logical sequences due to their default language structure.

In the second group, the book style was different. The results were achieved, but further testing of the seven step method is needed to determine if the same result can be accomplished with students who are more in the middle of the class versus the top.

Other discussion could center on how often to use these seven steps. Using it once per unit you could build chapters to the story. How many sentences are enough could be a discussion point, but mostly determined by the books used.

\section{Conclusions}

The program showed itself to be an efficient way to provide an option for the teacher. It was demonstrated to be effective using standard material for expansion of the lesson. There were some stressors due to new teaching style and culture, but these were quickly overcome. Is it possible to build a book length story over one semester using this method? As indicated, the students adjusted quickly and the time per unit/week could be set at one 60 -minute class.

More research needs to be done to discover if the change from the natural language structure deficiencies or default can be accelerated through a move to story-making. Further research would also be needed to determine if using a tense-focused style book versus a parts-of- speech style is more effective.

\section{References}

Cook, V. (2001). Second language learning and language teaching (3rd ed.). London: Arnold.

Friesen, P. R. (2013). Basic sentence. Dr. Roy’s everything grammar: Vol. I-Basic grammar: A 3D learning system (pp. 19-30).

New York: Strategic Book Publishing and Rights Co..

Fu, V. R., Stremmel, A. J., \& Hill, L. T. (2002). Teaching and learning. Upper Saddle River, New Jersey: Merrill Prentice Hall. Hashemi, L., \& Murphy, R. (1995). English grammar in use: With answers (1st ed.). Cambridge: Cambridge University Press. Nunan, D. (2003). Practical English language teaching. New York: McGraw-Hill/Contemporary.

Thomas, F., Beard, D., \& Cant, R. (Eds.). (2005). Grammar zone 2 workbook (pp. 28-32). Seoul, South Korea: Neungyule Education Inc..

Ur, P. (2008). A course in language teaching: Practice and theory. Cambridge: Cambridge University Press.

Venezky, R. L., \& Fisher, C. J. (1986). Ginn English. Lexington, MA: Ginn and Company.

\section{Appendix 1: Grammar Zone Step 2}

1 I've turned off the computer. So the computer is off now.

1 I turned off the computer last night. I don't know if it's off or on now.

2 He has been in the army for 10 years. He is in the army now.

2 He was in the army for 10 years. He's not in the army any more now.

3 Peter has broken his arm. Now his arm is still broken.

4 I have just finished lunch.

2 Have you ever had a part-time-job?

2 He has served as a police officer for 20 years.

1 Can I use your cell phone?

1 Sorry. I've left it at home. So I don't have it now.

4 Do you want to eat anything more? 
4 No, I've had enough. So now I'm full.

1 Do you know Lisa's e-mail address?

1 Oh, I'm sorry. I've forgotten it. So I don't know it now.

1 I forgot her e-mail address, so I couldn't e-mail her.

5 Is that book interesting?

5 I don't know. I've just read one page.

5 I've read just one page.

1 I've already searched the Internet but found nothing.

4 Are you ready to order?

4 Sorry, I haven't decided yet.

4 Have you eaten dinner yet?

4 Not yet. I think I'll skip it.

4 Have you already eaten dinner? That's a shame. I was going to take you out to eat.

6 Can I see the pictures you took last weekend?

6 Sorry, you can't, yet.

7 The light just went out. I can't see anything.

7 I'll look for some candles.

2 Have you managed to find a new room yet?

2 No, I (not / find) one yet.

8 Do you live with your family here in Seoul?

8 No, I’m living alone. I have lived here since 2001.

8 I've tried every way to contact him. Where on earth is he now?

$8 \mathrm{He}$ is in his country. Didn't you know that?

3, 5 Why didn't you go inside?

2 I can't find my keys. Maybe I left them at the office.

1 Have you ever bought anything on the Internet?

1 Sure. I've bought lots of things so far. In fact, just yesterday I bought some books online.

9 How many times has Brazil won the World Cup?

9 Five times! They won it in; 1958, 1962, 1970, 1994, and 2002.

9, 4 I’ve never seen him cry.

2 I've used the product before.

6 It was the most amazing film I've ever seen.

8 How long have you been married?

8 I've been married for 20 years.

8 I have lived in this apartment since 2001.

8 I have been living in this apartment since 2001. (Thomas et al., 2005, pp. 28-32)

Note: Some lines will have two numbers ( 9,4 as an example). This denotes the choice to use the sentence in two topics, or a possibility to use it in both.

\section{Appendix 2: Grammar Zone Step 4b}

\section{Computer}

1 I've turned off the computer. So the computer is off now.

1 I turned off the computer last night. I don't know if it's off or on now.

1 Can I use your cell phone?

1 Sorry. I've left it at home. So I don't have it now.

1 Do you know Lisa's e-mail address?

1 Oh, I'm sorry. I've forgotten it. So I don't know it now.

1 I forgot her e-mail address, so I couldn't e-mail her.

1 I've already searched the Internet but found nothing.

1 Have you ever bought anything on the Internet? 
1 Sure. I've bought lots of things so far. In fact, just yesterday I bought some books online.

Army

2 He has been in the army for ten years. He is in the army now.

2 He was in the army for ten years. He's not in the army any more now.

2 Have you ever had a part-time-job?

2 He has served as a police officer for 20 years.

2 Have you managed to find a new room yet?

2 No, I (not/find) one yet.

2 I can't find my keys. Maybe I left them at the office.

2 I've used the product before.

Health

3 Peter has broken his arm. Now his arm is still broken.

3, 5 Why didn't you go inside?

$\underline{\text { Sports }}$

9 How many times has Brazil won the World Cup?

9 Five times! They won it in; 1958, 1962, 1970, 1994, and 2002.

9, 4 I've never seen him cry.

Food

4 I have just finished lunch.

4 Do you want to eat anything more?

4 No, I've had enough. So now I'm full.

4 Are you ready to order?

4 Sorry, I haven’t decided yet.

4 Have you eaten dinner yet?

4 Not yet. I think I'll skip it.

4 Have you already eaten dinner? That's a shame. I was going to take you out to eat.

Books

5 Is that book interesting?

5 I don't know. I've just read one page.

5 I've read just one page.

$\underline{\text { Pictures }}$

6 Can I see the pictures you took last weekend?

6 Sorry, you can't, yet.

6 It was the most amazing film I've ever seen.

Lights

7 The light just went out. I can't see anything.

7 I'll look for some candles.

Family

8 Do you live with your family here in Seoul?

8 No, I'm living alone. I have lived here since 2001.

8 I've tried every way to contact him. Where on earth is he now?

8 He is in his country. Didn't you know that?

8 How long have you been married?

8 I've been married for 20 years.

8 I have lived in this apartment since 2001.

8 I have been living in this apartment since 2001. (Thomas et al., 2005, pp. 28-32)

Note: Some lines will have two numbers $(9,4$ as an example). This denotes the choice to use the sentence in two topics, or a possibility to use it in both. 


\section{UNIT \\ 05 현재완료형 I}

A 현재완료의 개념

우리말과는 달리 영어에는 과거시제와 현재시제 사이에 현재완료가 있다. 단순히 "과거에 어찌했다"라는 의미뿐만 아니라 "그런 과거 의 일로 인해 현재 어떠하다"라는 현재의 메시지까지 전달하기 위해 과거와 현재를 잇는 현재완료를 쓰는 것이다.

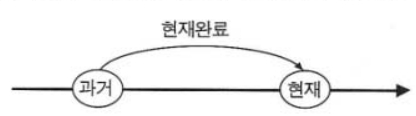

현재완료의 개념을 이해하기 위해서는 과거시제와의 차이점을 이해하는 것이 중요하다.

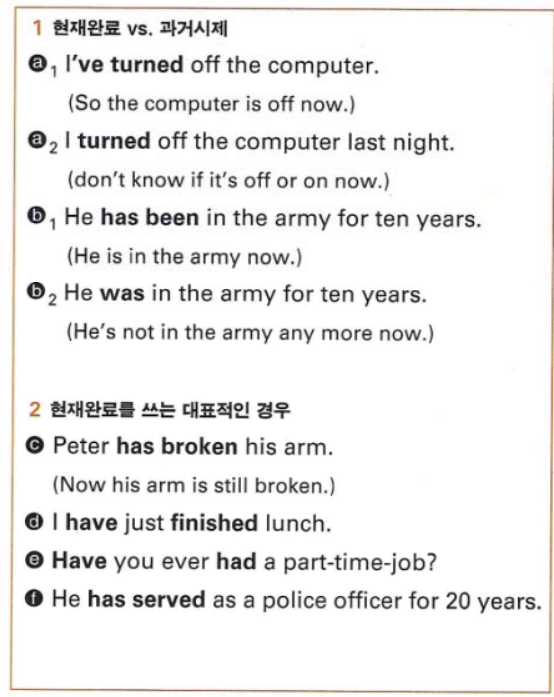

1 현재완료가 과거시제와 다른 점은 과거에 대한 정보 뿐만 아니라 현재에 대한 정보까지 준다는 것이다. $a_{1}$ 지금 현재도 꺼져 있다는 뜻

$a_{2}$ 단순히 어젯밤에 껐다는 과거 사실만 말할 뿐 현재 의 상황에 대해서는 말하고 있지 않다.

$0_{1} 10$ 년 전부터 현재까지 군대에 있다는 뜻

$\sigma_{2}$ 예전에 군대에 있었다는 과거 사실을 나타낸다. 현 재는 군대에 없다는 것을 강하게 암시하고 있다.

2

() 결과: 과거의 일이 현재 어떤 결과를 낳을 때

(6) 완료: 과거에서 시작하여 최근 또는 방금 전에 완료 된 일을 나타낼 때. 방금 전은 과거라고 하기엔 현 재와 너무나도 가깝다.

(e) 경험: 과거부터 현재까지의 기간 동안 경험한 것을 나타낼 때

(9) 계속: 과거부터 현재까지 계속되는 일을 나타낼 때

serve as 로 복무하다 / police officer 경찰관

\section{B '결과' 를 나타내는 현재완료}

과거의 일로 인해 현재에 어떤 결과가 생겼을 때 현재완료를 쓴다. 이때 해석은 ' 했다' 로 과거시제와 같지만 현재와의 연관성이 있 기 때문에 '그래서 지금은 어떠하다' 라는 결과의 의미까지 포함되어 있다.

(a) A: Can I use your cell phone?
B: Sorry. I've left it at home. (So I don't have it now.)

28 | G-zone a 전화기를 집에두고 온 결과 지금 가지고 있지 않은 상태(I have left $\rightarrow$ I've left)

Figure 1. Sample page of a standard grammar book used in South. Source: Adapted from Thomas et al., 2005, p. 28. 